Social Work/Maatskaplike Werk Vol 55 No 1; Issue 2

http://socialwork.journals.ac.za/pub doi:http://dx.doi.org/10.15270/55-1-692

AUTHENTIC TEACHING, LEARNING AND ASSESSMENT: REAL-WORLD EXPERIENCES OF FOURTH-YEAR STUDENTS IN A SOCIAL WORK MODULE

Hanna Nel, Erica Pretorius

This article reports on a fourth-year social work module attempting to develop employable social work students rather than preparing students for employment in the context of social work. The Edinburgh Napier University clarifies the distinction: "Employment is about getting a job" and "Employability is about having an effective mix of skills, attributes and attitudes to function successfully in required roles" in the real world of work.

It argues that over and above providing content knowledge, 21st-century skills should also be integrated into the actual module. Recent evidence suggests that there is a missing link between higher education graduates' learning and their readiness for today's world of work. The results from this qualitative investigation revealed that students found the teaching, learning and assessment activities challenging, but also reported that these activities contributed towards their holistic readiness for employment.

hannan@uj.ac.za, ericap@uj.ac.za 



\section{AUTHENTIC TEACHING, LEARNING AND ASSESSMENT: REAL-WORLD EXPERIENCES OF FOURTH-YEAR STUDENTS IN A SOCIAL WORK MODULE}

\section{Hanna Nel, Erica Pretorius}

\section{NTRODUCTION}

Resnick (1987) proposed the idea of "bridging apprenticeships", which introduced the notion of integrating theory into practice. This implies that higher education institutions should attempt to apply theory in real-world situations. However, evidence shows that many lecturers at higher education institutions find it difficult to bridge the gap between theory and practice. They still engage in the traditional outmoded teaching approaches of one-way transfer of theoretical knowledge (Herrington \& Herrington, 2006; Herrington \& Kervin, 2007). Busteed (2014:14), Gallup's executive director of education and workforce development, mentioned that "the most recent evidence suggests that the link between higher education and graduates' readiness for today's rapidly changing workplace may be broken". He also commented that a representative sample indicated that $96 \%$ of academics believed that their institutions prepared students effectively for the world of work. However, from the world of work, only $14 \%$ of the American public and $11 \%$ of business leaders agreed that students graduated with the required competencies and skills for the real world of work. Similarly, Rodríguez-Gómez and Ibarra-Sáiz (2015) argue that many higher education institutions still associate assessment processes with assignments and examinations simply awarding grades for mostly theoretical, paper submissions. In South Africa Scott, Yeld and Hendry (2007) contend that there is a substantial misalliance between the skills required for a real-world working career and the output of graduates from higher education institutions. The above statements draw attention to the question of whether universities are really succeeding in preparing students for the workplace.

Consequently, this article argues that teaching, learning, assessments and formal summative examinations at higher education institutions should be designed to include authentic career-orientated activities as part of the formal theoretical curriculum. Lecturers should transform their approach in order to view formative assessments and assignments as tools for learning and empowerment (Rodríguez-Gómez \& Ibarra-Sáiz, 2015). Designing teaching, learning and assessment activities necessitates tapping into the theoretical concepts, yet at the same time promoting the development of real-world working skills. This should include higher-order learning by using particular learning designs, focusing specifically on authentic activities (Herrington \& Herrington, 2006). This article explores student experiences during the implementation of authentic teaching, learning and assessment tasks in an existing social work module on management and administration at the University of Johannesburg (UJ).

This research project uses a qualitative applied approach, as it looks into student experiences of both formative and summative authentic assessment activities. The results from this qualitative investigation revealed that students found the teaching, learning and assessment activities challenging, but also reported that such activities contributed towards their holistic readiness for employment.

Firstly, we will set the context of the study and then offer an overview of real-world learning as one of the authentic learning and assessment principles (Ashford-Rowe, Herrington \& Brown, 2014). This will be followed by a brief discussion of the research approach and methods used in this study. The results, findings and reflections will then be presented and discussed. The recommendations will be followed by concluding remarks, providing a summary of the overall findings. 


\section{AUTHENTIC LEARNING IN THE CONTEXT OF SOCIAL WORK AT THE UNIVERSITY OF JOHANNESBURG}

The UJ teaching and learning strategy promotes a learning-to-be philosophy (University of Johannesburg, 2014). Therefore, in addition to simply acquiring content knowledge as in the traditional teaching model, this social work module aimed to incorporate authentic real-life knowledge, skills and values. The learningto-be philosophy underpins this research project, which promulgates the view that teaching and learning at UJ should transform from mere information transmission (learning about) to the practices of acquiring real-world knowledge, skills and attitudes (learning to be) (University of Johannesburg, 2014). This philosophy recommends that teaching and learning should support both social and individual knowledge construction. In addition, it requires that teaching should stimulate the transformation of information into knowledge, preparing students with enquiring minds to solve problems rather than for mere information regurgitation. Furthermore, it promotes engaging activities whereby students participate meaningfully in a collaborative learning environment, enhancing diverse thinking alongside the practices of a specific discipline. It requires well-designed tasks focusing on achieving predefined learning outcomes within the diverse social, cultural, economic and linguistic perspectives of South African higher education (Hornsby \& Osman, 2014). Moreover, it encourages continuous reflection to advance teaching and learning practices promoting ongoing research.

Consequently, a lecturer in social work at UJ followed an authentic teaching and learning approach to prepare final-year students for real-world jobs. A blended learning and assessment approach was used in this module, employing both face-to-face and online interactions. Blackboard, as the official learning management system of UJ, was the most suitable platform and technological tool for this purpose. No student was disadvantaged in any way as all students had access to either a computer laptop, tablet or smartphone on campus. The improved access to technology encouraged this study to incorporate authentic teaching, learning and assessment elements into this module. The formative quiz activities included continuous assessment tasks which scaffolded the required content knowledge to apply in the summative assignment for this module. The students were required to complete a real-world task of finding solutions to secure funding for an actual social service organisation in South Africa. The teaching and learning strategic drive of learning-to-be at UJ embraces authentic teaching, learning and assessment principles, and real-world 21st-century skills were incorporated into the theoretical framework for this article.

\section{THEORETICAL CONSIDERATIONS}

Much literature on higher education in the 21 st century focuses on the practices of authentic teaching, learning and assessment (Lombardi, 2007; Binkley, Erstad, Herman, Raizen, Ripley, Miller-Ricci \& Rumble, 2012; Kereluik, Mishra, Fahnoe \& Terry, 2013; Ashford-Rowe, et al, 2014). The teaching, learning and assessment process followed in this module related specifically to the principle of realworld relevance.

Rodríguez-Gómez and Ibarra-Sáiz (2015) endorse assessment as a tool to promote both learning and empowerment. They argue that learning and empowerment are products of an assessment activity, which includes elements from both lifelong learning and sustainable assessment. Lifelong learning is an ongoing activity throughout life, aimed at improving knowledge, skills and competences as a formative and sustainable assessment process which is developmental in nature. Moreover, Kearney (2013:877) argues that "a fast-changing, technologically driven twenty-first-century labour force is a by-product of an education that fosters the growth of the individual learner by encouraging the development of skills that are crucial to sustainable and autonomous learning". Sustainable assessment refers to developing the students' transferable skills as a foundation for lifelong autonomous learning. These 21st-century transferable skills are sustainable in that they support future ecological and socially responsible decision-making skills.

Assessment, as learning and empowerment, presents challenges in that the assessment process demands of students to be involved in a transparent and dialogical manner. This transparent and dialogical 
approach requires a two-way conversation between the lecturer and students. It demands a formative assessment strategy described as feedforward, whereby the lecturer and students employ strategies and comments that contribute proactively towards producing a progressive polished outcome. These fundamental challenges scaffold the design of high-quality assessment activities. Moreover, this approach stresses the need for assignments to be demanding, meaningful and authentic. This requires students to employ reflective and analytical thought processes as a real-world skill (Rodríguez-Gómez \& Ibarra-Sáiz, 2015). Activities need to include the real-world tasks relating to the specific discipline, in this case social work, which students could analyse critically and reflect upon. The activities should simulate an environment where students work actively inside a realistic and social context of the discipline. Therefore the product of the assessment task should offer a stronger alignment between the actual task and the conditions of social work. The activity should meet the purpose of real-world abilities such as the core work-related skills, knowledge and attitudes required by the profession (Ashford-Rowe, et al, 2014; Lombardi, 2007). The authors as the facilitators of this module attempted to include the theoretical concepts mentioned in this paragraph. The concepts of lifelong learning, sustainable assessment, assessment as empowerment and feedforward feature implicitly in the actual implementation of this module and are seen as essential elements for the real world of work.

In the world of work, activities are often performed as a team which is working towards the same desired goal of the profession or the organisation. However, the traditional education system promoted individualism and memorisation of content knowledge. West (2012) argues that organisational achievements are dependent on teamwork as this outshines the combined efforts of individuals working alone. As an example, the quality of society life improves if people work jointly towards achieving shared goals. Diverse teams can reinforce, inspire and motivate all team members to add value to an organisational goal. Teamwork actively and purposefully encourages effective relationships, as well as inter-team relationships within the wider organisation. It enables effective communication where new creative and innovative ideas are shared, the workload divided and mutual support is offered. Skills, knowledge and opportunities are utilised to full capacity when working in a team (West, 2012).

In addition to teamwork skills, the 21st century is associated with the use of various information and communication technologies as primary resources. Therefore technical, communication, writing and organising skills are essential in today's technologically orientated workplace (Mansour \& Dean, 2016). Pellegrino and Hilton (2013) contend that students' employability is influenced by their technological and face-to-face communication skills. Both written/oral communication and technical skills are essential for working effectively with others. Many students, especially in South Africa, still lack basic technological skills and experience in using computers. They find it challenging not only to communicate electronically, but also to compile their written assignments (Czerniewicz \& Brown, 2013). Bansal (2014) argues that following a blended approach for teaching, learning and assessment is more advantageous for developing countries such as South Africa. The authors believe that the blended learning approach holds the promise to promote enhanced learning and assessment in the multicultural South African context. It increases opportunities for students to interact with their diverse peers and lecturers as well as offering opportunities for flexible active and self-directed learning (Larkin, 2014; Bansal, 2014).

Despite following a flexible self-directed learning approach in this assignment, it is also acknowledged that organisational goals and objectives are linked to specific timeframes. Predetermined deadlines are crucial to success in an organisation. Therefore, students need to practise time management as a basic real-world skill when completing an assignment. Coping with the workload and delivering projects on time are vital skills for students to master before they enter the real world of work (Bendoly, Swink \& Simpson, 2014). Yet working in groups and integrating real-world time management skills are still challenging for social work students at higher education level.

Mansour and Dean (2016) argue that, alongside time management, interpersonal skills are essential in terms of employability. According to Lewis, Packard and Lewis (2007), to be effective in the workplace requires polished interpersonal skills. These skills include conflict management, negotiation, 
professionalism and ethics. Moreover flexibility, commitment and coping skills are essential to survive in the real world of work (Williams, 2015). The reality of working in the real world also involves being challenged, often demanding more effort and perseverance. Lev Vygotsky (1896-1934) promulgates the concept of the zone of proximal development - claiming that with scaffolding, rather than mere spoon-feeding, students can be challenged to provide more advanced outcomes (Chaiklin, 2003). Accordingly, Ashford-Rowe, et al (2014) contend that the diverse activities should also address this critical element of real-work life in challenging students to produce useful and more advanced artefacts. Therefore, the complex activities should not be designed only to require clear-cut or evident responses, as students need to construct their own unique artefact by applying existing theory and information (ibid). The activity should be complex and designed as an ongoing process of investigation, integrating both real-world skills and subject content knowledge.

Despite all the skills mentioned, subject content knowledge should not be neglected. Content knowledge alongside theory offers scaffolding in promoting the understanding of specific situations. Content knowledge is fundamental to problem-solving, creativity, innovation and even the creation of new knowledge. Without existing knowledge, students will not be able to contest such knowledge or build on it to develop new understandings and ideas (Christodoulou, 2013). Therefore content knowledge should be fundamental when integrating additional skills for student employability. Content knowledge relevant for this assignment included management and leadership skills within the context of human service organisations and programmes as well as skills in project management.

\section{RESEARCH METHOD}

This research project followed a qualitative approach, which allowed optimal opportunities for the participants to disclose their diverse and rich social interactive experiences while adding value to the ultimate usefulness of the project (Roller \& Lavrakas, 2015). The aim of this study was to review the students' feedback on their experiences of the different types of authentic teaching, learning and assessment. Quantitative data were mainly used to support the qualitative findings as a form of data triangulation (Denzin, 2012). Students were required to carry out a systematic inquiry and apply social work knowledge, skills and values to achieve the outcome of compiling a funding proposal. This study employed an applied research design in that it took place in the specific context of a social work module at UJ.

Ninety-one (91) fourth-year students participated in this project. These participants included a blend of various ethnic groups. There were, among others, Zulu, Xhosa, Sepedi and White students, as well as students from other ethnic groups on the African continent. All students completed the formative multiple-choice online assessments, which aimed at scaffolding the students' content knowledge of this module in preparation for the summative assignment of compiling a funding proposal.

Data from the actual module were mainly used to gauge the level of participation of the students in the interactive online activity. The summative assignment attempted to provide a more nuanced preparation of these fourth-year students for a real-life career of working in a social service environment. These assignments included elements relating to real-world experiences as part of the teaching, learning and assessment process. Students participated in online groups during the planning, design and development of the required proposal assignment. Students had to use a real-world welfare organisation for this activity. From the onset of the assignment, students had a detailed rubric (feedforward) available to guide their efforts in the design and development of the fundraising proposal. Students used both technology and face-to-face interactions to communicate and collate their decisions on the funding proposal. This made the task authentic as students could communicate in their own languages with each other and compile a product using topics and graphics appropriate to the South African context. The instructions and guidelines were posted on the Blackboard learning management system to provide a secure and authentic online learning environment. 
In addition to the actual activities for this module, an online survey was the primary method for collecting the qualitative data. Only 44 of the 91 students completed the survey resulting in an acceptable response rate of $48 \%$. The authors used ATLAS.ti as an electronic analysis tool to analyse the data. This type of coding data analysis allowed for identifying categories and themes. The exploratory data collected revealed the authentic teaching, learning and assessment experiences of the students (Friese, 2014). The responses of the students contained numerous grammatical and spelling errors which were corrected. This is also an indication of the language barriers faced by South African multilingual students.

Applied research examines a specific instance and links the results to the specific situation and context. The data of this type of research are directly applicable to real-world situations (Krueger \& Casey, 2014). This is evident in this study, which took into account ethical considerations, as well as the experimental and descriptive nature of the project. Ethical clearance was obtained from the relevant committee at UJ and all student responses were anonymous and confidential. Students gave written consent for their participation in this project. Hence, the results of this project could be considered trustworthy.

\section{RESULTS AND DISCUSSION}

In our analysis we firstly identified the themes related to real-world skills within the concepts of authentic teaching, learning and assessment. Overall, negative and positive comments emerged from the students' responses in the survey relating to real-world skills.

Table 1 summarises the results from the students' responses on real-world knowledge, skills and attitudes. The overall results indicated that the students were exposed to numerous real-life skills, as they completed the activity of designing and developing a fundraising proposal. The students had to employ subject-specific and interdisciplinary knowledge, skills for work and personal skills in compiling this funding proposal. The responses were arranged according to the most prevalent theme, categories and sub-categories.

\section{TABLE 1}

\section{RESULTS: REAL-WORLD SKILLS, KNOWLEDGE, VALUES AND ATTITUDES}

\begin{tabular}{|l|c|l|c|}
\hline Theme & Categories & \\
\hline \multirow{4}{*}{ Theme 1: Skills for work } & \multirow{3}{*}{57} & Teamwork skills & 29 \\
\cline { 3 - 4 } & & Technical/writing/communication & 15 \\
\cline { 3 - 4 } & & Time management & 11 \\
\cline { 3 - 4 } & & Organising skills & 2 \\
\hline \multirow{4}{*}{$\begin{array}{l}\text { Theme 2: Personal skills } \\
\text { attitudes and values }\end{array}$} & \multirow{2}{*}{27} & $\begin{array}{l}\text { Interpersonal skills (relations and conflict } \\
\text { management) }\end{array}$ & 14 \\
\cline { 3 - 4 } & & Coping skills & 6 \\
\cline { 3 - 4 } & & Commitment & 4 \\
\cline { 3 - 4 } & & Perseverance & 3 \\
\hline Theme 3: Subject knowledge & 16 & Subject content knowledge & 16 \\
\hline
\end{tabular}

Scores indicate the importance students allocated to the different components.

In the table above the ratings indicate that students consider real-world working skills more significant than actual subject content knowledge for their future opportunities of employability. The results further show that students also regard personal skills, attitude and values as more important than basic subject content knowledge.

Figure 1 represents graphically the sequence of importance that the students accorded the various categories. 


\section{FIGURE1}

\section{CATEGORY RESPONSE RATING}

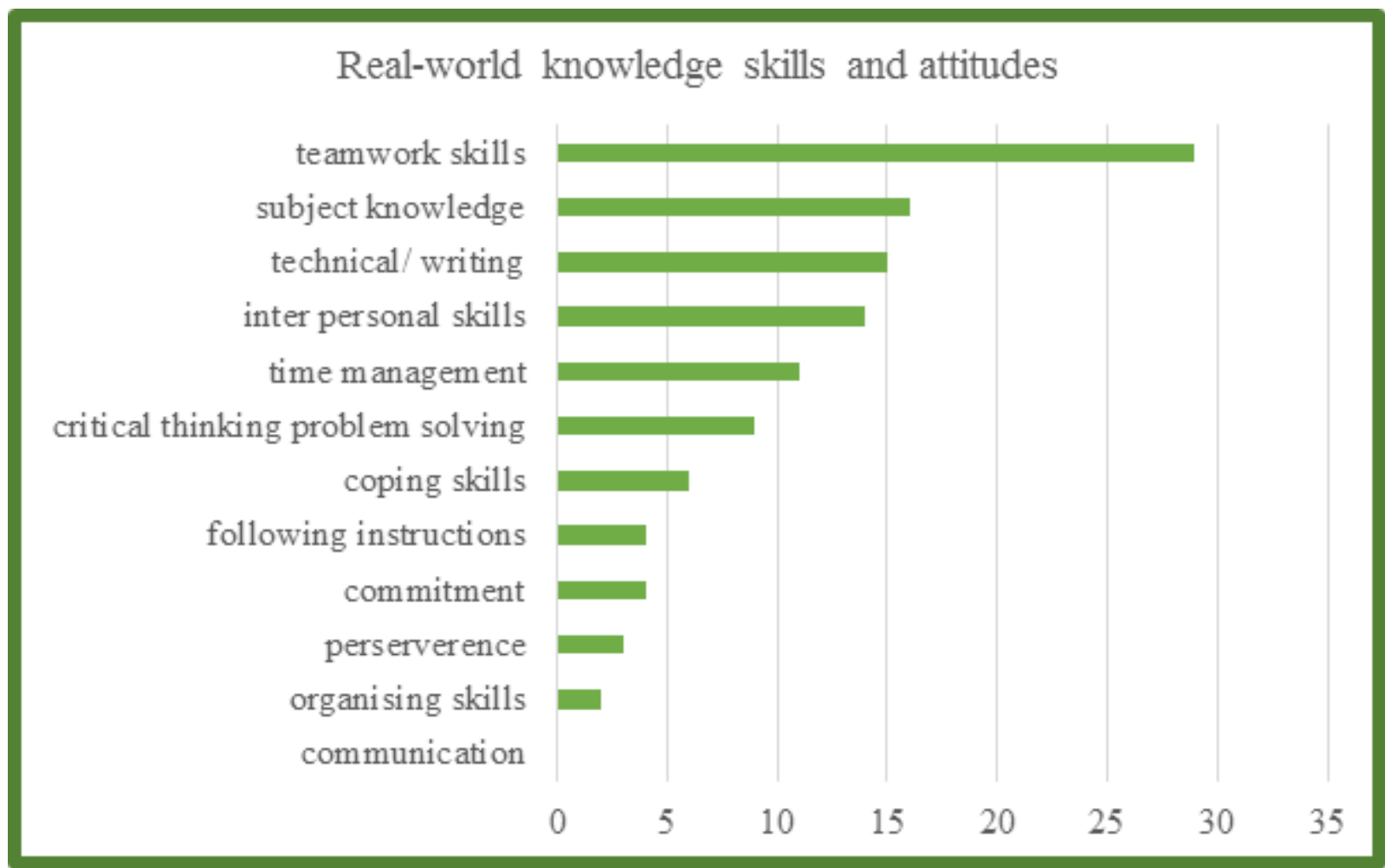

Figure 1 highlights that students consider teamwork to be the most essential element required for working in a real-world social work environment. However, they also consider subject content knowledge as more important than personal knowledge, skills and attitudes in the working environment. The findings below are discussed in the sequence as presented above.

\section{Theme 1: Skills for work}

\section{Teamwork}

The most prominent category identified from the results is teamwork. However, not all comments relating to working in a team were positive, which indicated that students still require more skills to work in a team. The responses indicate that working in a team can also be challenging. Some students might have good skills, real-life experiences of working in a team, but if all role players do not contribute to the teamwork it could also be a negative experience.

Students mentioned:

"They either did not do the work assigned or they had other excuses."

"In the beginning it was not easy to get people to get together."

"It was a chaos and a bad experience. I believe I could have gotten more than what I got had I been working alone."

These responses indicate that some students have not yet realised that companies work together as teams to achieve the same desired outcome or goal. This usually relates to productivity or profitability and is not equated with achieving individual success or, as at university, a pass or fail mark during an exam.

A student commented in this regard: 
"Working in groups is always a challenge because you are reliant on people for marks, whose work ethic may be totally different to yours, and who may or may not be as committed as you are to studying. I would have preferred doing the project on my own."

Overall, the comments related to teamwork were more positive as some students almost seemed to have matured to accept the importance of teamwork required for the real world of work.

Student comments:

"Though it was challenging in terms of our differences, we managed to come to one point that made us work on it together." (negotiation skills)

"Sharing ideas such as putting together a funding proposal and ... what was relevant and not." (improved output)

"I managed and learned to delegate work ..." (delegation)

“... correcting my work and even helping me with reference and how to look for information." (peer support)

“... to discuss each week in order our work to be congruence." (shared vision, goal)

Although the evidence shows that the students' teamwork skills were still in the developmental phase, much improvement was noted during this project. The evidence of the students' responses above also highlighted Coulshed and Mullender's (2001) statement that sharing ideas, dividing the workload, and learning and supporting are essential elements to achieving shared goals and overcoming challenges. According to Potgieter (2003), the effective management of people in teams can produce higher performance levels and greater organisational effectiveness.

\section{Technical skills}

In addition to working in teams, the authors also identified digital and information literacy as a fundamental skill requirement for success in the world of work in the digital age.

Student comments were:

"I had challenges with signing up for a group."

"Since not everyone has internet access at their places."

"We felt it was easier for us to have meetings on campus..."

“...we ended up opening a group what's up because all of us had WhatsApp.”

“...we were using Whats App to organise meetings."

The responses from students confirmed that using multiple types of technology for both written and oral communication is not a new phenomenon for this generation - a point confirmed by the literature (Mansour \& Dean, 2016; Pellegrino \& Hilton, 2013). Yet it is important to acknowledge that there are also some students in need of additional support in using technologies. At UJ there are support systems in place to assist these students in need of developing their technological skills.

\section{Writing and communication skills}

The funding proposal activity also improved the writing and communication skills of the students such as their writing abilities and use of technologies.

Student comments:

"I feel that I have learned to structure the Funding Proposal much better ... and improve on the quality of proposals one can produce."

“... student development of communication and writing skills.” 
“... writing a proposal is one of the fundamental skills that we have to know as social workers as we need to apply for funds often."

Student responses indicated that students' writing and communication improved during the compilation of the funding proposal. Kereluik, Mishra, Fahnoe and Terry (2013) substantiate that both written and oral communication are basic skill requirements for 21st-century learning and working in the real world. Furthermore, writing of funding proposals is a prominent skill which social workers need to be competent in (Lewis, Packard \& Lewis, 2007; Herbst, 2014).

\section{Time management}

Time management is essential in any real-life work environment as organisations have pre-determined deadlines. Workload timing and delivering projects on time is a vital skill for students to master before they enter the real world of work (Bendoly, Swink \& Simpson, 2014; Pretorius, 2014). Despite the importance of time management, only one positive comment was made about saving time when working together on an assignment.

A student commented:

"Reason being that as a group we are able to think beyond an individual and tasks finish quicker than when working alone."

However, the evidence showed that students need much scaffolding in managing their time better before they actually graduate and enter the workplace (Pretorius, 2014). The responses included:

"If one has to do the assignment individually it would be much appreciated if more time was given to complete the assignment."

"The assignment required a lot of time."

"Bad time management."

\section{Organising skills}

In doing this assignment students also required organising skills alongside time management. Organising is seen as one of the four basic management functions, defined as the process of arranging and allocating of work, authority and resources (Nel, 2014). Their comments indicated that they still required guidance to accomplish organising their tasks with their peers in allocating duties to the different group members/role players.

Student comments:

"It was challenging getting together to coordinate our work. As each part had to flow into the other."

"In the beginning it was not easy to get people to get together."

"We have to keep record by managing all that we do as social workers."

"Learning to give instructions."

In addition to skills for work as discussed above, people also need personal skills, attitudes and values in order to interact socially and emotionally in the work environment.

\section{Theme 2: Personal skills, attitudes and values}

In any profession people need basic personal skills such as communicating with colleagues and even coping skills to manage workload (Lewis, Packard \& Lewis, 2007; Hellriegel, Slocum, Jackson, Louw, Staude, Amos, Klopper, Louw, Oosthuizen, Perks \& Zindiye, 2012). The responses of the students are categorised under interpersonal relationships, conflict management, coping skills, commitment and perseverance. The responses from students highlighted both positive and negative interactions during the completion of this group activity. 


\section{Interpersonal relationships}

Many students offered excuses leading to strained interpersonal relationships among specific group members. In addition there were also differences of opinion, given the multicultural nature of our student population.

The negative comments from students included:

"It was a challenging experience because every group member had their own different view..."

"... felt isolated within the group."

However, many students persevered and some groups worked well together despite their differences, as seen in the responses below:

"... when it comes to team because I got a chance to learn more about myself and also learnt not to be selfish."

"... at the end came to a mutual agreement."

"... we learnt something from each other as a group."

"We shared ideas without criticizing each other."

"... though it was challenging in terms of our differences but we managed."

“... as we people we are different and we definitely want things to go according to our ways and in group work there is none like that we had to work together despite our personalities but to focus on one relevant thing."

The group activity offered students the opportunity to experience working with different cultures. It was a learning curve for the students as they reflected on both their own behaviour and that of their fellow students. From the above comments it is evident that students were challenged on basic interpersonal relationships, attitudes and values. Embedded in interpersonal relationships are the attitudes and values of students in the relationships. Aspects such as commitment, accommodation of different views and open to learning from others could be seen as attitudinal features and represent values that are usually linked with relationships (Nel, 2014; Maier, Tavanti, Bombard, Gentile, \& Bradford, 2015).

\section{Conflict management}

Students reported that they experienced a number of communication barriers which can be associated with interpersonal relationships. These barriers demanded negotiation and conflict management skills. A better understanding of the world of work and the profession scaffolds future workplace interactions in different contexts (Pellegrino \& Hilton, 2013). Work contexts also include conflict situations, which means that students need to develop conflict-resolution skills. Consequently the group-work approach addressed this need in that it also allowed students to develop conflict-resolution strategies where necessary.

Student responses:

"Our group had a number of communication barriers."

"... we argued a lot and it was difficult to come with solutions."

"Not so good because some group members weren't doing their parts ..."

"There were ups and downs ..."

Cultural and language differences also caused conflict as a result of communication barriers and differing opinions. The feedback indicated that conflict situations in fact arose as a result of the lack of accountability in that students did not take responsibility for doing their allocated tasks. As mentioned 
above, using a funding proposal in a social work context offered students the opportunity to interact and to resolve conflicts in this context.

\section{Coping skills}

Some students showed a lack of coping skills as they struggled to produce the required input for the group funding proposal.

Student comments are evidence of a lack of coping skills:

"Some group members weren't doing their parts properly putting a strain on the person that was compiling the assignment at the end."

"It was very challenging. We had to walk long distance ..."

"One of the group members was sick..."

From this response the authors deduced that some students revealed a tendency to cope better under strenuous conditions than others. The world of work can be very demanding and often one person ends up producing more than others in a particular working environment. Therefore it is essential that students gain coping skills to manage everyday challenges that they may be presented with in the real world of work. Moreover, this experience cultivated feelings of caring and consideration for each other (Williams, 2015).

\section{Commitment and perseverance}

Commitment is a critical skill and value in order to be a productive asset in any workplace (Williams, 2015). Students need to display commitment towards their career and organisation which, as this assignment indicated, presented a challenge to some students. Many students, for example, were simply working for marks and did not display personal commitment to the task at hand or even focused on gaining additional knowledge and skills.

Student comments include:

"In the academic sector it is not as easy as working with someone for something that is not for marks."

“... group members produced poor quality work."

Commitment also relates to perseverance in working until the final product has been achieved successfully (Hellriegel, et al, 2012; Williams, 2015).

Student comments were:

"To climb the corporate ladder you need perseverance and do the best you can."

"Though we did not have a break but I enjoyed ..."

Student responses varied in that some students showed more determination and persistence than others. However, this activity created an awareness of perseverance in achieving the final objective, which is an important skill for the world of work and specifically the social work profession.

\section{Theme 3: Subject-specific and interdisciplinary knowledge}

This article promoted social learning, but it did not neglect the idea of fundamental subject content knowledge required to scaffold real-world implementation. Subject-specific knowledge is a basic requirement for students to achieve a degree in social work. For this purpose, formative assessments in the form of multiple quizzes were employed to reinforce specific concepts and subject-specific knowledge in this discipline. The subject-specific knowledge relevant for this module was linked to the administration and management of human service organisations in general and the compilation of a funding proposal specifically, within the context of a social development paradigm, using various 
sources in this regard (Coulshed \& Mullender, 2001; Lewis, Packard \& Lewis, 2007; Engelbrecht, 2014).

Developing a funding proposal for a specific social work organisation entailed inter-disciplinary knowledge as well. This selected organisation case study and the funding proposal also demanded knowledge related to social work, financial concerns, community development and human service organisations. The funding proposal task in the social work context also involved financial knowledge and skills such as compiling a budget to address the monetary needs of this particular project, administration, management and leadership skills.

Student responses relating to subject-specific content knowledge were:

"... the prescribed book, it was local and relevant to my context."

"It also helped me gain more knowledge about what to look for when writing a funding proposal."

“... to learn and be prepared on how we can draft our proposals during practice."

“... explaining what administration and management entails in social work practice.”

“... I learnt a lot about administration and management."

"I now have experience on how to work with different people and using different management skills."

This activity encompassed various domains and discipline-specific knowledge. In this activity the lecturer linked unrelated knowledge, skills, values and attitudes to apply the required curriculum content into a simulated real-world scenario in the compilation of a funding proposal.

In general, the students' responses were in favour of the integrated approach. The responses below confirm this recommendation:

"I think the module gives a good introduction to management in social work, which is something we have never been exposed to previously."

"It was an eye opener for me and helped me to see social work in a different perspective."

"The module is a great module that prepares us for the field, but the way it is taught it needs to be changed, or this module can be part of the internship module because it goes hand in hand with the internship."

The student responses were mostly positive indicating that this module was presented in a different way. They noticed that it was not only focused on static social work content, but also included soft skills required for the social work profession in the real world of work.

\section{CONCLUSIONS}

The main purpose of this article was to report on a fourth-year social work module attempting to develop employable students rather than preparing students for employment in the context of social work. The Edinburgh Napier University clarifies the distinction: "Employment is about getting a job" and "Employability is about having an effective mix of skills, attributes and attitudes to function successfully in required roles" in the real world of work.

This article incorporated the idea of "bridging apprenticeships" by introducing the notion of integrating theory into practice. This was achieved by applying theory in the real world of work. Online quizzes were employed to reinforce subject-specific content knowledge. These content-related quizzes also prepared the students for their formal summative exam in obtaining their assessment for the module on management and administration, as part of obtaining the degree in Social Work. Over and above providing content knowledge, the researchers integrated work-related 21st-century skills to prepare 
students for the real world of work. The overall findings indicated that students participated enthusiastically in the group activity of compiling the funding proposal.

Despite the challenges of working in groups, students gained personal skills and developed positive attitudes and values alongside the compulsory subject content knowledge. The personal skills gained included teamwork skills, technical and writing skills, time management and organising skills. They experienced ways of working with different cultures, developing their interpersonal skills that are essential for working in the South African multicultural context. The group-work activity developed the coping and conflict-management skills of the fourth-year social work students. It also enhanced the students' sense of commitment and perseverance. It is interesting that many of these 21 st-century workrelated skills are also highlighted as important skills when managing programmes and projects in social service organisations.

Through this interactive group-work activity students could participate in a more interactive way than if the facilitators would have done it in a top-down way, where primarily theory would have been provided.

It could also be concluded that this exercise gave this big group of students the opportunity to participate in a joint task, which would have been difficult if the facilitators focused only on teaching of content. Students were thus far more involved and interactive in this module.

The need for students to develop personal and professional soft skills was thus highlighted in this study. Lastly, some students suggested further integration of subject content knowledge with 21 st-century skills and knowledge in the internship modules. This means that there should be a tighter link between the theory modules, 21 st-century skills and knowledge, and the internship modules.

\section{RECOMMENDATIONS}

This study highlighted the possibilities within the realm of social work to prepare the students for realworld employability, which is often neglected in traditional assessment practices at higher education institutions. Despite social work being an applied discipline offering internships, it still mostly favours traditional content delivery and assessment practices for formal examination and promotion purposes. The authors acknowledge that Social Work is actually making some progress in terms of integrating subject content knowledge with real-world experiences, but there is still room for improvement in this regard. It is thus recommended that various creative and innovative teaching, learning and assessment methodologies could be integrated in linking 21 st-century skills and knowledge with content-specific knowledge, skills and values.

As the social work classes are usually very big, it is thus recommended that these various creative teaching and learning methods could be utilised in preparing students for employability rather than employment at higher education institutions.

\section{REFERENCES}

ASHFORD-ROWE, K., HERRINGTON, J. \& BROWN, C. 2014. Establishing the critical elements that determine authentic assessment. Assessment \& Evaluation in Higher Education, 39(2):205-222.

BANSAL, P. 2014. Blended learning in Indian higher education: Challenges and strategies. International Journal of Applied Research and Studies, 3(2):1-13.

BENDOLY, E., SWINK, M. \& SIMPSON, W.P. 2014. Prioritizing and monitoring concurrent project work: Effects on switching behavior. Production and Operations Management, 23(5):847-860.

BINKLEY, M., ERSTAD, O., HERMAN, J., RAIZEN, S., RIPLEY, M., MILLER-RICCI, M. \& RUMBLE, M. 2012. Defining twenty-first century skills.” In: GRIFFIN, P., McGAW, B. \& CARE, E. (eds). Assessment and teaching of 21st century skills. Dordrecht: Springer. 
BUSTEED, B. 2014. The education economy: America's next big thing. Business Journal [Online] Available: $\quad$ http://www.gallup.com/businessjournal/174275/education-economy-america-next-bigthing.aspx. [Accessed: 19/08/2017].

CHAIKLIN, S. 2003. The zone of proximal development in Vygotsky's analysis of learning and instruction. In: KOZULIN, A., GINDIS, B., AGEYEV, V. \& MILLER, S. (eds). Vygotsky's educational theory and practice in cultural context. Cambridge: Cambridge University Press.

COULSHED, V. \& MULLENDER, A. 2001. Management in social work. ( $2^{\text {nd }}$ ed). Hampshire: Palgrave Press.

CHRISTODOULOU, D. 2013. Minding the knowledge gap: The importance of content in student learning. American Educator, 38(1):27-33.

CZERNIEWICZ, L. \& BROWN, C. 2013. The habitus of digital 'strangers' in higher education. British Journal of Educational Technology, 44(1):44-53.

DENZIN, N.K. 2012. Triangulation 2.0. Journal of Mixed Methods Research, 6(2):80-88.

EDINBURGH NAPIER UNIVERSITY. What is the difference between employment, employability and graduate attributes? [Online] Available: http://staff.napier.ac.uk/services/sas/student_development/EnhancingtheCurriculum/graduate_attributes/Pages/Differentiatinge mployment,employabilityandGraduateAttributes.aspx. [Accessed: 20/09/2017].

ENGELBRECHT, L.K. (ed) 2014. Management and supervision of social workers: Issues and challenges within a social development paradigm. United Kingdom: Cengage Learning.

FRIESE, S. 2014. Methods and methodologies for qualitative data analysis. In: Proceedings of the ATLAS.ti User Conference 2013: Fostering dialog on qualitative methods [Online] Available: http://dx.doi.org/10.14279/depositonce-4827. [Accessed: 08/11/2017].

HELLRIEGEL, D., SLOCUM, J., JACKSON, S.E., LOUW, L., STAUDE, G., AMOS, T., KLOPPER, H.B., LOUW, M., OOSTHUIZEN, T., PERKS, S. \& ZINDIYE, S. 2012. Management. $4^{\text {th }}$ ed. South Africa: Oxford University Press.

HERBST, A. 2014. Programme and project management tasks. In: ENGELBRECHT, L.M. (ed) Management and supervision of social workers: Issues and challenges within a social development paradigm. United Kingdom: Cengage Learning.

HERRINGTON, A. \& HERRINGTON, J. (eds) 2006. Authentic learning environments in higher education. Hershey, PA: IGI Global.

HERRINGTON, J. \& KERVIN, L. 2007. Authentic learning supported by technology: Ten suggestions and cases of integration in classrooms. Educational Media International, 44(3):219-236.

HORNSBY, D.J. \& OSMAN, R. 2014. Massification in higher education: Large classes and student learning. Higher Education, 67(6):711-719.

KEARNEY, S. 2013. Improving engagement: The use of 'authentic self- and peer assessment for learning' to enhance the student learning experience. Assessment \& Evaluation in Higher Education, 38(7):875-891.

KERELUIK, K., MISHRA, P., FAHNOE, C. \& TERRY, L. 2013. What knowledge is of most worth: Teacher knowledge for 21 st century learning. Journal of Digital Learning in Teacher Education, 29(4):127-140.

KRUEGER, R.A. \& CASEY, M. 2014. Focus groups: A practical guide for applied research. ( $5^{\text {th }}$ ed). Thousand Oaks, CA: Sage Publications.

LARKIN, T.L. 2014. The student conference: A model of authentic assessment. International Journal of Engineering Pedagogy, 4(2):36-46. 
LEWIS, J.A., PACKARD, T.R. \& LEWIS, M.D. 2007. Management of human service programs. $\left(4^{\text {th }}\right.$ ed). Australia: Thomson Brooks/Cole.

LOMBARDI, M.M. 2007. Authentic learning for the 21st century: An overview. Educause Learning Initiative, $1: 1-12$.

MAIER, T., TAVANTI, M., BOMBARD, P., GENTILE, M. \& BRADFORD, B. 2015. Millennial generation perceptions of value-centered leadership principles. Journal of Human Resources in Hospitality \& Tourism, 14(4): 382-397.

MANSOUR, B. \& DEAN, J. 2016. Employability skills as perceived by employers and university faculty in the fields of human resource development (HRD) for entry level graduate jobs. Journal of Human Resource and Sustainability Studies, 4(1):39.

NEL, H. 2014. Management functions. In: ENGELBRECHT, L.M. (ed) Management and supervision of social workers: Issues and challenges within a social development paradigm. United Kingdom: Cengage Learning.

PELLEGRINO, J.W. \& HILTON, M.L. (eds) 2013. Education for life and work: Developing transferable knowledge and skills in the 21st Century. Washington, DC: National Academies Press.

POTGIETER, T. 2003. The dynamics of groups and teams. In: SCHULTZ, H. (ed) Organisational behaviour: A contemporary South African perspective. Pretoria: Van Schaik.

PRETORIUS, E. 2014. Essential management tasks. In: ENGELBRECHT, L.M. (ed) Management and supervision of social workers: Issues and challenges within a social development paradigm. United Kingdom: Cengage Learning.

RESNICK, L.B. 1987. The 1987 presidential address: Learning in school and out. Educational Researcher, 16(9):13-54.

RODRÍGUEZ-GÓMEZ, G. \& SOLEDAD IBARRA-SÁIZ, M. 2015. Assessment as learning and empowerment: Towards sustainable learning in higher education. In: PERIS-ORTIZ, M. \& MERIGÓ LINDAHL, J.M. (eds). Sustainable learning in higher education. Springer Verlag International Publishing.

ROLLER, M.R. \& LAVRAKAS, P.J. 2015. Applied qualitative research design: A total quality framework approach. New York: Guilford Press.

SCOTT, I., YELD, N. \& HENDRY, J. (eds) 2007. Higher education monitor no. 6: A case for improving teaching and learning in South African higher education. Pretoria: Council on Higher Education.

UNIVERSITY OF JOHANNESBURG. 2014. Learning and Teaching Report. [Online] Available: https://www.uj.ac.za/about/.../learning\%20and\%20teaching\%20report\%202014.pdf. [Accessed 08/09/2017].

WEST, M.A. 2012. Effective teamwork: Practical lessons from organizational research. 3rd ed. West Sussex: John Wiley \& Sons.

WILLIAMS, A.C. 2015. Soft skills perceived by students and employers as relevant employability skills. Minneapolis: Walden University.

Prof Hanna Nel, Department of Social Work; Dr Erica Pretorius, Centre for Academic Technologies, University of Johannesburg, South Africa. 